\title{
Geochemistry of some ferruginous soils of Kerala, India
}

\author{
P. N. Dubey ${ }^{*}$, B. P. Bhaskar ${ }^{2}$, P. Chandran ${ }^{2}$, B. $\operatorname{Singh}^{1}$ and B. K. Mishra ${ }^{1}$ \\ ${ }^{1}$ National Research Centre on seed Spices, Ajmer-305206 (Rajasthan), INDIA \\ ${ }^{2}$ Division of Soil Resource Studies, National Bureau of Soil Survey and Land Use Planning, Nagpur-440033 \\ (Maharashtra), INDIA \\ *Corresponding author. E-mail: pradyumnnarayan@yahoo.co.in \\ Received: May 26, 2015; Revised received: September 26, 2015; Accepted: February 12, 2015
}

\begin{abstract}
The four representative ferruginous soils on lateritic cover developed over Precambrian rocks in parts of Kottayam of Kerala were studied to understand the weathering pattern and genesis through geochemistry. These soils are strongly to moderately acidic, reddish brown with low Cation exchange capacity CEC and base saturation having $\mathrm{SiO}_{2}-33$ to $57 \%, \mathrm{Al}_{2} \mathrm{O}_{3}-16-31 \%, \mathrm{Fe}_{2} \mathrm{O}_{3}-8$ to $15 \%$ and $\mathrm{TiO}_{2}-0.7$ to $1.4 \%$. Kanjirapalli (P3) and Athirampuzha (P4) soil series were more intensely weathered as compared to the Kinalur (P1) and Chingavanam series (P2) with silica to alumina-iron ratio less than 2 and had a significant negative relationship with Chemical index of alteration CIA $\left(-0.75^{* *}\right)$, Harnois index $\left(-0.678^{* *}\right)$, Richie index $(-$ $\left.0.953^{* *}\right)$ and Plagioclase Index of Weathering $\left(-0.705^{* *}\right)$. The trace elemental concentration ranges were above the values of world soils having an enrichment index more than 1 in Kanjirapalli series (P3) and $\mathrm{Ni}$ contamination in genetic horizons $\left(\mathrm{Ni}>200 \mathrm{\mu gg}^{-1}\right)$. The cluster analysis showed similar major oxide concentration pattern in Group -1 and Group - 2 but varied in trace elemental pattern with $\mathrm{Cr}>\mathrm{Ba}>\mathrm{Cu}$ in Group - 1 and $\mathrm{Cu}>\mathrm{Cr}>\mathrm{Ba}$ in Group - 2 soils whereas $\mathrm{Zr}>\mathrm{Ni}>\mathrm{Mn}$ in Group -3 to $\mathrm{Ni}>\mathrm{Mn}>\mathrm{Zr}$ in Group -4 soils. The study further showed that differential rate of weathering in soils under tropical climate was further accelerated due to anthropogenic activities such as improper land use practices and deforestation on sleep slopes.
\end{abstract}

Keywords: Chemical index of weathering, Enrichment index, Index of laterization, Kerala, Trace elements

\section{INTRODUCTION}

Chemical weathering is one of the most important processes that change the chemical composition of soils and distribution of elements in weathering products that differ from parent rocks (Nesbitt and Markovics, 1997). Chemical compositions of soils have been used effectively to evaluate weathering and soil formation conditions, to trace the provenance of soils (Nesbitt et al., 1996) and to reconstruct paleoclimate records (Zabel et al., 2001; Wei et al., 2004). Thus, quite a number of studies have been carried out in the past several decades to investigate chemical weathering (Price et al., 1991; Little and Aeolus Lee, 2006). Previous studies show elements that are conserved in temperate zone, such as $\mathrm{Ti}$ and $\mathrm{Zr}$, are mobile during extreme chemical weathering in tropical regions (Cornu et al., 1999). Probing into element behaviour during weathering is pivotal to understanding element mobilization and redistribution during chemical weathering. In addition, laterites, the products of extreme weathering, account for over $85 \%$ of the present world soil cover (Nahon, 2003).

Quantitative characterization of weathering in soils is made through development of weathering indices (Price and Velbel, 2003; Abbaslou et al., 2013 and
Yousefifard et al., 2014). The chemical index of alteration (CIA, Nesbitt and Young, 1982), chemical index of alteration (CIW, Harnois, 1988) and plagioclase index of alteration (Fedo et al., 1995) serve as examples of the decomposition of unstable minerals. According to the principles of soil genesis, alkali and alkaline earth elements move through soil horizons prior to silicon as weathering progresses (Souri et al., 2006). Laterite and lateritic soils are formations peculiar to India and some other tropical countries with intermittently moist climate. In India they cover a total area of about 248,000 sq. Kilometres in the states of Deccan, Karnataka, Kerala, Madhya Pradesh, Eastern Ghat regions of Orissa, Maharashtra, Malabar and parts of Assam (Raychaudhuri, 1980) but cover onefourth of the total geographical area of 329 millon ha on the basis of soil resource inventory (Sehgal, 1998 and Bhattacharyya et al., 2009 ).

The general characteristics of laterite associated soils in Kerala were reported by Satyanarayana and Thomas (1962) and of Nellore district in Andhra Pradesh by Bhaskar and Subbaih (1995). The geochemical trends in lateritic profiles of Kerala were reported by Narayanaswamy (1992) indicating the depletion of silica and enrichment of sesquioxides and $\mathrm{TiO}_{2}$ during the process of weathering. Later, Ramahashay et al.(1987) 
reported the occurrence of halloysite in association with kaolinite, goethite, gibbsite and quartz in these soils possessing high plasticity and cation exchange capacity. Silica as invariant was used to work out geochemical mass balance sheet of laterite associated soils of Somasila project (Bhaskar et al., 1999). The distinguishing feature of these laterite soils is development of strong chroma and redder hue accumulation of clay, and relatively minor accumulation of $\mathrm{Fe}$ and $\mathrm{Al}$ sesquioxides in the B horizons where in silica to sesiquioxide ratio is less than 2 (Chandran et al., 2005).

The recent review on pedology of red ferruginous soils of India was made by Pal et al (2014) describing several pedological and edaphological aspects of alfisols, mollisols and ultisols mainly of humid tropical climate but little emphasis was made on geochemical records of these soils. .The lateritic soils are dominant in Southern mid land zone (SMZ) mostly used for rubber (Hevea brasiliensis) under terraced hill slopes from Tiruvananthapuram to Kottayam. The intensive monsoon climate in the region is strongly interlinked with strong chemical weathering of lateritic soils and occurrence of devastating land slides. Among various geo-environmental factors, slope plays vital role for many land use associations and cautious towards necessity of adopting land use control. In India, therefore, comprehensive understanding of the behaviour of elements during extreme weathering in the tropical laterite profile may aid in our understanding of the mechanisms of weathering and for drawing meaningful geotechnical measures in the region. There is scanty of literature on geochemical interpretations of lateritic soils dealing with elemental organizations as controlled by geology in Kerala. Hence in the present study, an attempt has been made for geochemical characterization of lateritic soils from parts of Kottayam, Kerala (India) to decipher the pedogenic association and interrelationships of these soils with geology and bioclimatic conditions.

\section{MATERIALS AND METHODS}

Details of study area: The study area is part of southern midland zone of Kerala and confined to the parts of Kottayam, Ernakulam and Kozhikode where Precambrian rocks like charnockites with narrow bands of pyroxene granulites and magnetite-quartz rocks are dominant (Damodaran, 1955). In Nilambur Valley, Kozhikode district, magnetite - quartzite, pyroxene and hornblende granulites and charnockite gneiss constitute the charnockite group (Sawarkar, 1980). Broadly, the soils of this region have been categorized as red sandy or sandy clay loams (Kamath, 1985) or more specifically by Bourgeon (1989) as mainly ferrallitics (French soil taxonomy) or subgroups of Ultisols, Alfisols and Inceptisols as per USDA soil taxonomy (USDA, NRCS, 2008). Kerala has substantial portion of laterites (around 60 percentage of the exposed surface area Krishnan et al., 1996 and Haridranath et al.,
1999) developed over rocks of different composition and age. South midland zone of Kerala receives mean annual rainfall of $3265 \mathrm{~mm}$ from early June to late September. The soil moisture regime is ustic with soil temperature regime of Isohyperthermic (Eswaran et al., 1990) with a length of growing period of 210 to 270 days (Sehgal et al., 1992). The dominant natural vegetation comprises of Canarium strictum, Mesa ferrea, Dipterocarpus spps., Callophylum elatum, Cullinia excels, Palaquium ellipticum, Tectonia grandis, Terminalia tomentosa, Dalbergia latifosa, Xylia xylocarpa, Pterocarpus marsupium, Santalum album, Avecinnia spps., Rhizophora spps., etc. Patches of scrub vegetation with other xerophytic plants are found in association with tropical fruit trees like jack fruit and cashew.

The soil profiles under study in the midlands $(\leq 300 \mathrm{~m})$ of Kerela (Fig. 1) were as follows.

P1: Kinalur series $\left(11^{\circ} 28^{\prime} 00^{\prime \prime} \mathrm{N}\right.$ latitude and $75^{0} 50^{\prime} 00^{\prime}$ 'E longitude) is a member of clayey, kaolinitic, Ustic Kanhaplohumults. These soils are very deep, well drained, dark red, gravelly sandy clay loam surface and red to reddish brown gravelly sandy clay sub soils with argillic horizon occurring on uplands and mounds.

P2: Chingavaram series $\left(9^{0} 44^{\prime} 00^{\prime} \mathrm{N}\right.$ latitude and $76^{0} 51$ ' $48^{\prime}$ 'E longitude) is a member of loamy skeletal, kaolinitic, family of Typic Kandiustults . These soils are deep, well drained dark red surface horizons and red argillic Bt horizons with sandy clay loam texture. These soils occur on midlands having $>15$ per cent slopes.

P3: Kanjirapalli series $\left(9^{0} 33^{\prime} 00^{\prime} \mathrm{N}\right.$ latitude and $76^{\circ} 47^{\prime} 00^{\prime}$ 'E longitude) is a member of clayey-skeletal, kaolinitic, Ustic Kandihumults. These soils are very deep, well drained formed on charnokite with dark reddish brown gravelly sandy clay loam surface and red to reddish brown gravelly sandy clay sub soils with argillic horizon occurring on uplands mounds and hills having more than $30 \%$ slopes.

P4: Athirampuza series $\left(9^{0} 39^{\prime} 34^{\prime} \mathrm{N}\right.$ latitude and $76^{0} 31$ ' $35^{\prime}$ 'E longitude) is a member of clayey-skeletal, kaolinitic, Ustic Kanhaplohumults. These soils are deep, well drained formed on laterized rocks (charnokites) with yellowish red gravelly clay surface and red to yellowish red gravelly argillic clay subsoils. This soil occurs on uplands, mounds and hills having slopes more than 30 per cent. This is a competing series of Arur series (Harindranath et al., 1999).

Laboratory analysis: Horizon wise soil samples for each soil series were collected and passed through $2 \mathrm{~mm}$ sieve after air drying. The fine earth fraction was used for laboratory analysis for particle size distribution (International pipette method), $\mathrm{pH}(1: 2.5)$, organic carbon (OC, Walkley Black), cation exchange capacity (CEC) and exchangeable bases (ammonium acteate) and percent base saturation was estimated as sum of bases/CEC*100. The ECEC (Effective cation exchange capacity) was derived as summation of ex- 
Table 1. Summary of weathering indices formula.

\begin{tabular}{|c|c|c|}
\hline Index & Formula & References \\
\hline $\begin{array}{l}\text { Chemical index of } \\
\text { alteration (CIA) }\end{array}$ & $\mathrm{CIA}=\mathrm{Al}_{2} \mathrm{O}_{3} / \mathrm{Al}_{2} \mathrm{O}_{3}+\mathrm{Na}_{2} \mathrm{O}+\mathrm{CaO}=\mathrm{K}_{2} \mathrm{O}^{*} 100$ & $\begin{array}{l}\text { Nesbit and Young } \\
\text { (1989) }\end{array}$ \\
\hline WIP & $\left(2 * \mathrm{Na}_{2} \mathrm{O} /(0.35)+(\mathrm{MgO} / 0.90)+\left(2 * \mathrm{~K}_{2} \mathrm{O}\right) 0.25\right)+(\mathrm{CaO} / 0.70) * 100$ & Parker (1970) \\
\hline $\mathrm{Si} / \mathrm{Al}$ & & Birkeland (1999) \\
\hline $\begin{array}{l}\text { Bases/Alumina } \\
\text { Bases/R2O3 }\end{array}$ & & \\
\hline Reiche product index (RPI) & $100 *\left(\mathrm{SiO}_{2}\right) /\left(\mathrm{SiO}_{2}+\mathrm{R}_{2} \mathrm{O}_{3}\right)$ & Reiche (1943) \\
\hline Vogt ratio & $\mathrm{Al}_{2} \mathrm{O}_{3}+\mathrm{K}_{2} \mathrm{O} / \mathrm{MgO}+\mathrm{CaO}+\mathrm{Na}_{2} \mathrm{O}$ & Vogt (1927) \\
\hline Weathering Ratio (WR) & $\left(\mathrm{CaO}+\mathrm{MgO}+\mathrm{Na}_{2} \mathrm{O}\right) / \mathrm{TiO}_{2}$ & Chittleborough(1991) \\
\hline Weathering Index -1 & $\left(\mathrm{CaO}+\mathrm{SiO}_{2}\right) /\left(\mathrm{Fe}_{2} \mathrm{O}_{3}+\mathrm{TiO}_{2}\right)$ & Darmody (2005) \\
\hline Weathering Index -2 & $\left(\mathrm{CaO}+\mathrm{SiO}_{2}\right) /\left(\mathrm{Al}_{2} \mathrm{O}_{3}+\mathrm{Fe}_{2} \mathrm{O}_{3}+\mathrm{TiO}_{2}\right)$ & \\
\hline Ignition loss index & $\mathrm{H}_{2} \mathrm{O} *$ & Jayawardena (1994) \\
\hline
\end{tabular}

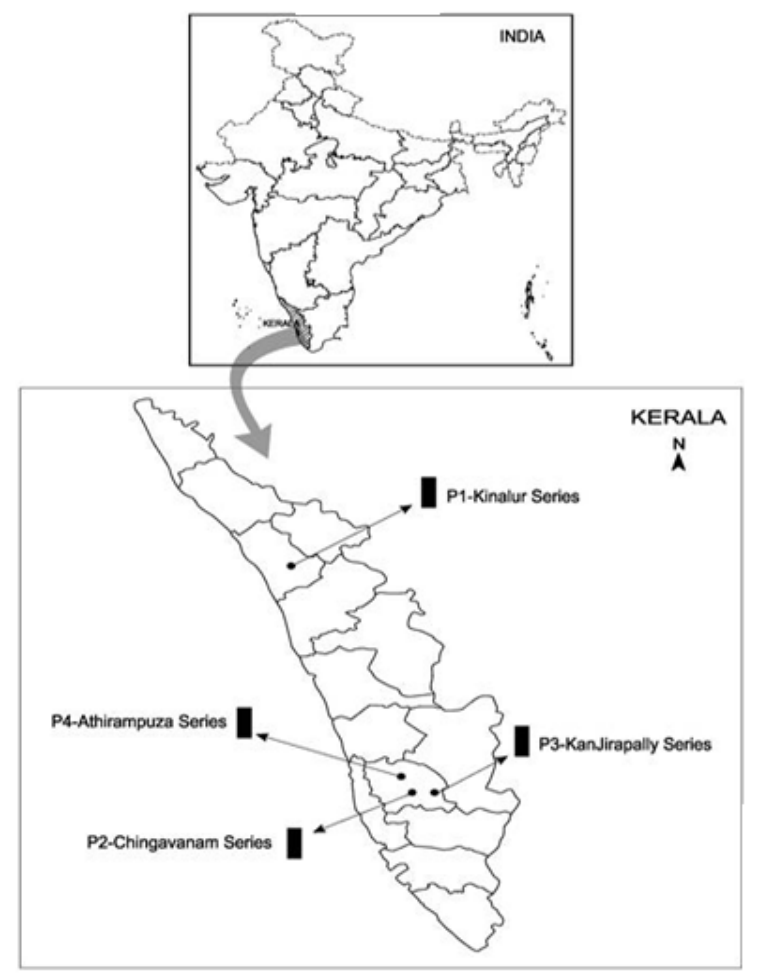

Fig. 1. Location map of soil profiles under study in Kerala.

changeable aluminium and exchangeable bases. 1M $\mathrm{KCl}$ extractable aluminium was determined titrimetricaly, apparent CEC and ECEC was estimated as CEC/ clay*100 and ECEC/clay*100 (Sarma et al., 1987; Jackson, 1975).

Elemental analysis was carried out using $1 \mathrm{~mm}$ soil fraction by acid digestion (HF) for all elements except silica. Silica was estimated separately by sodium carbonate fusion using platinum crucibles (Page et al., 2002). Molar concentrations were estimated by dividing the elemental concentrations with atomic weight of the elements. The weathering indices were calculated by various methods as listed in table 1 .

\section{RESULTS AND DISCUSSION}

Soil characteristics: The characteristics red and lateritic soils of Kerala developed over granite (P1), laterite (P2 and P3) and charnokite (P4) are listed as below
Dendrogram using average linkage (between groups) rescaled distance cluster combine

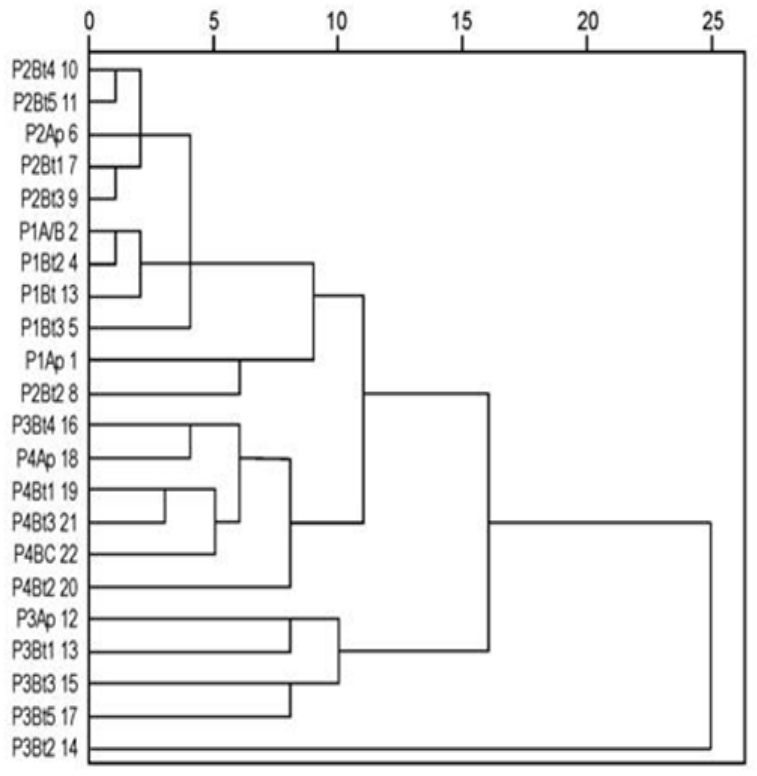

Fig. 2. Soil grouping based on geochemical data.

and presented in table 2 . Kinalur series (P1) have $10 \mathrm{~cm}$ thick, dark brown, very strongly acid $(\mathrm{pH}<4.5)$ A horizons and have $70 \mathrm{~cm}$ thick kandic dark reddish (5YR3/4) to reddish brown(5YR4/4) or red $(2.5 \mathrm{YR} / 6)$ strongly acid (pH of $5.1-5.5$ ) with more than $30 \%$ clay and base saturation less than $35 \%$ to classify than under the subgroup of Ultisols. The kandic horizon has an apparent CEC less than $16 \mathrm{cmol} / \mathrm{kg}$ clay and an apparent ECEC less than $12 \mathrm{cmol} / \mathrm{kg}$ within $100 \mathrm{~cm}$ to further classify Kanhaplic Haplustults. The very strongly acid Chingavanam series (P2) have $15 \mathrm{~cm}$ thick, dark red (2.5YR3/6) Ap horizons and red (2.5YR4/6) to reddish brown (2.5YR4/4) clay rich kandic horizons ( 30 to $36 \%$ clay) with base saturation less than $35 \%$, to classify as Typic Kandiustults.

The very strongly acid Kanjiraplli series (P3) and Athiram puzha series (P4) are classified as Ustic Kandihumults because these soils have an organic carbon more than 0.9 per cent in upper $15 \mathrm{~cm}$ of kandic horiozon with low base saturation. These soils have reddish brown Ap horizons (5YR3/3 to 3/4) and dark 


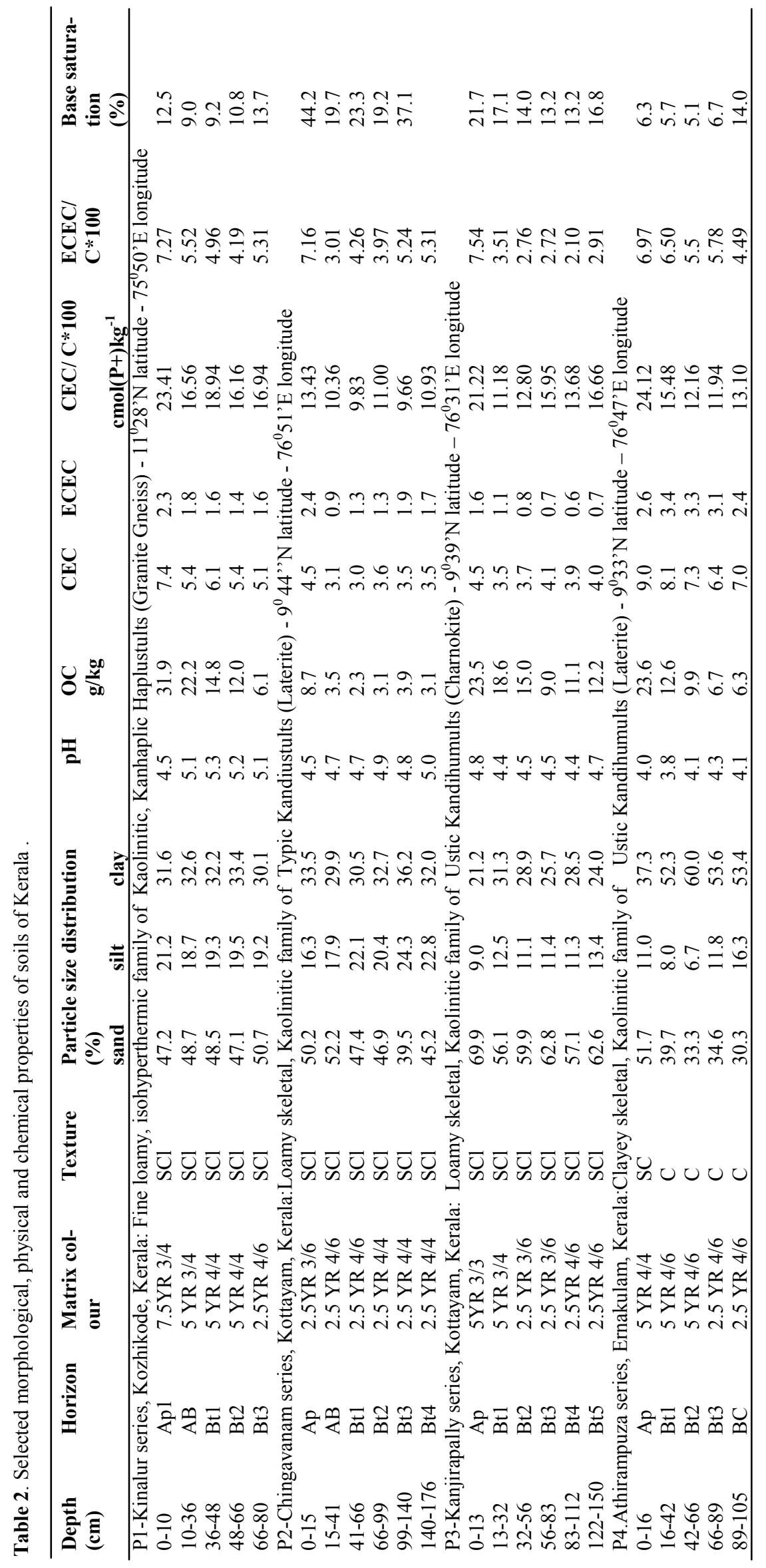


P. N. Dubey et al. / J. Appl. \& Nat. Sci. 8 (1) : 196 - 207 (2016)

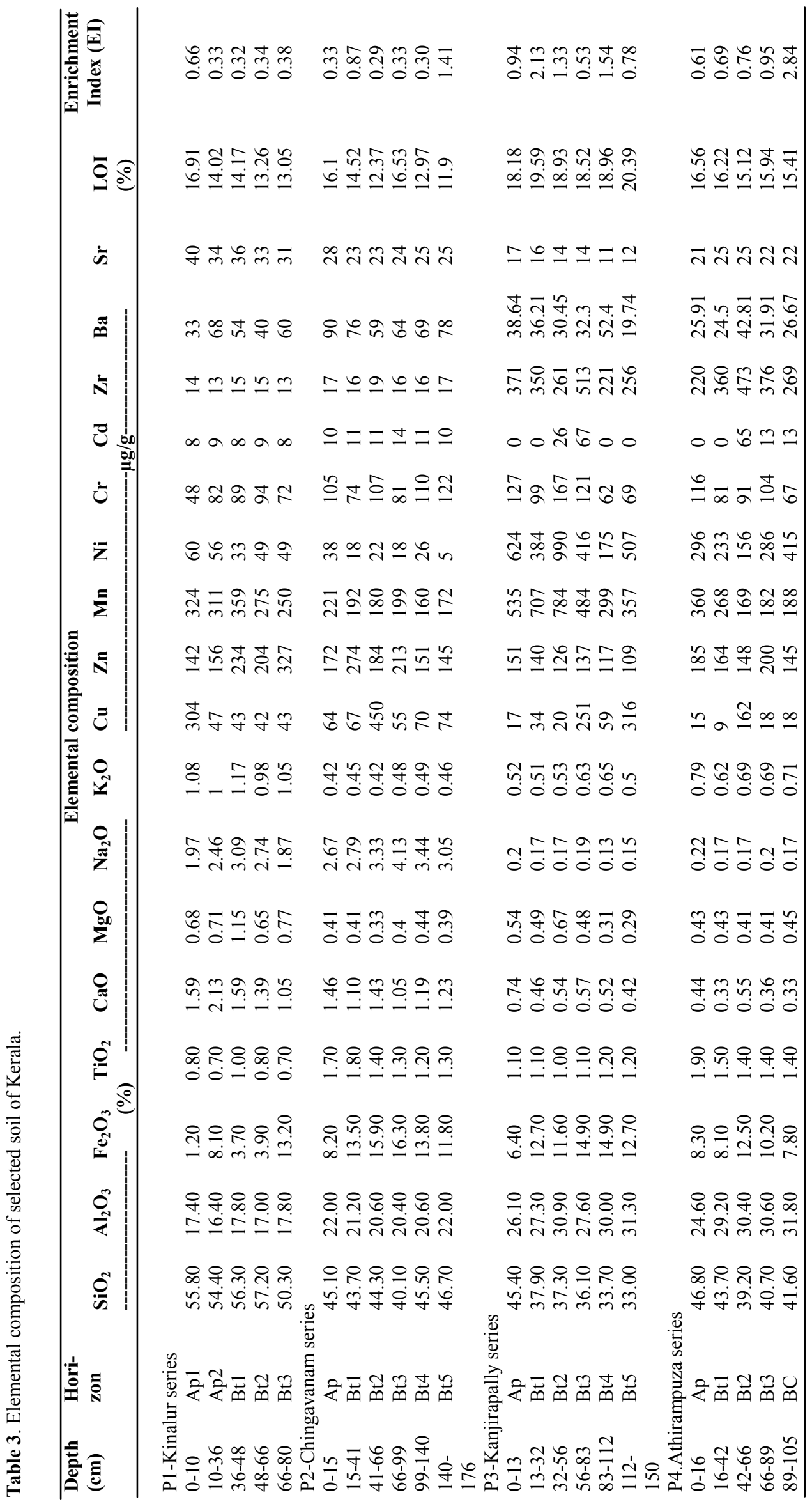


Table 4. Geochemical grouping based on elemental affinity in soils of Kerala.

\begin{tabular}{llll}
\hline Clusters & Horizon sequences & Major elements & Trace elements \\
\hline Group -1 & P2Bt4- 2Bt5- P2Ap-P2Bt3 & $\mathrm{Si}>\mathrm{Al}>\mathrm{Fe}>\mathrm{Na}>\mathrm{Ti}>\mathrm{Ca}>\mathrm{K}>\mathrm{Mg}$ & $\mathrm{Mn}>\mathrm{Zn}>\mathrm{Cr}>\mathrm{Ba}>\mathrm{Cu}>\mathrm{Sr}>\mathrm{Ni}>\mathrm{Zr}$ \\
Group-2 & P1Bt3-P1Bt4-P1A/B-P1Bt2- & & $\mathrm{Mn}>\mathrm{Zn}>\mathrm{Cu}>\mathrm{Cr}>\mathrm{Ba}>\mathrm{Ni}>\mathrm{Sr}>\mathrm{Zr}$ \\
& P1Bt1-P1Ap-P2Bt2 & & \\
Group-3 & P3Bt4-P4Ap-P4Bt1-P4Bt3- & $\mathrm{Si}>\mathrm{Al}>\mathrm{Fe}>\mathrm{Ti}>\mathrm{K}>\mathrm{Ca}>\mathrm{Mg}>\mathrm{Na}$ & $\mathrm{Zr}>\mathrm{Ni}>\mathrm{Mn}>\mathrm{Zn}>\mathrm{Cr}>\mathrm{Cu}>\mathrm{Ba}>\mathrm{Sr}$ \\
& P4BC-P4Bt2 & & $\mathrm{Ni}>\mathrm{Mn}>\mathrm{Zr}>\mathrm{Zn}>\mathrm{Cr}>\mathrm{Cu}>\mathrm{Ba}>\mathrm{Sr}$ \\
Gropu-4 & P3Ap-P3Bt1-P3Bt3-P3Bt5- & & \\
& P3Bt2 & & \\
\hline
\end{tabular}

reddish brown (5YR3/4, P5) to reddish brown(5YR4/6, P4) but changed to red $(2.5 \mathrm{YR} 4 / 6)$ in lower kandic horizons. The texture is uniformly sandy clay loam in Kanjirapalli series (P3) but of clay in case of Athirampuzha series (P4). The apparent CEC and ECEC are similar to that of kandic horizons reported elsewhere in India (Bhaskar et al., 2005; Bhattacharyya et al., 2006). The occurrence of kandic gentic horizons in ferruginous soils of rubber growing areas in Kerala and Tamil nadu were reported (Krishnan et al., 1996). The kandic horizons have set of properties resembling ferralic horizon with low $\mathrm{CEC}(<4 \mathrm{cmol} / \mathrm{kg}$ in sub horizons of B) and apparent effective cation exchange capacity $<12 \mathrm{cmol}_{\mathrm{c}} \mathrm{kg}-1 \mathrm{clay}$ and cation exchange capacity $<16 \mathrm{cmol}_{\mathrm{c}} \mathrm{kg}-1 \mathrm{clay}$ with thickness more than $30 \mathrm{~cm}$ (FAO, 2006). It is interesting to mention here that the top soils of these profiles meet the criteria to define as modic that display characteristics like incompletely mineralized OM (intensive rubber growing area and frequent additions of leaf) and an OC content of $>0.6$ percent, blackish brownish in the hue of 5YR with base saturation $<10$ per cent and $\mathrm{pH}<5.0$ (FAO, 1998). The occurrence of modic topsoils in ferruginous soils of Shillong plateau were reported and proposed to use modic at subgroup level for Sombrihumults in Shillong plateau (Bhaskar et al., 2009). The difficulties in identifying the clay skins in argillic horizons in soils of Kerala and in Northen states was very well expressed in review of red ferruginous soils of India by Pal et al., 2014 and places some soils in the subgroups of Dystrudepts.

Elemental composition: The elemental composition of four lateritic and associated soils of Kerala is presented in table 3. Among major elemental oxide, $\mathrm{SiO}_{2}$ is dominant with it gradational decrease in concentrations to less than 40 per cent in kandic horizons of Kanjirapalli series(P3) but 40 to $50 \%$ with irregular trends in Chingavanam series (P2) and Athirampuzha series $(\mathrm{P} 4)$ and exceeding 50 per cent in Kinalur series (P2). Next to $\mathrm{SiO}_{2}, \mathrm{Al}_{2} \mathrm{O}_{3}$ concentration is 25 to 31 per cent with irregular depth trends in Kanjirapalli (P3) and of increasing trends in Athirampuzha series (P4). The Chingavanam series (P2) have $\mathrm{Al}_{2} \mathrm{O}_{3}$ concentration of 20 to 22 per cent with fairly uniform depth distribution but less than 20 per cent in Kinalur (P1, irregular trends). The $\mathrm{Fe}_{2} \mathrm{O}_{3}$ content is 3.7 per cent in kandic $\mathrm{B}$ horizons $(\mathrm{P} 1)$ and reached to a maximum of 16.3 per cent in $\mathrm{Bt} 3$ horizon of $\mathrm{P} 4$. These soils have 1.1 to 2.2 per cent of $\mathrm{TiO}_{2}$ with high concentration of
$1.9 \%$ in $\mathrm{P} 4$ but decrease its concentrations in Bt horizons. The concentration of alkali and alkaline earth elements are less than 1 per cent in majority of soil horizons with the exceptions in soils where $\mathrm{CaO}$ and $\mathrm{Na}_{2} \mathrm{O}$ exceed $1 \%(\mathrm{P} 1 / \mathrm{P} 2)$.

Trace elements: Trace elements concentration in the lateritic profiles is mainly driven by weathering of bedrocks .Trace elements are defined as those elements that are present at concentrations below $1000 \mathrm{mgkg}^{-1}$ or $0.1 \%$ (Rollinson, 1993). The distribution of trace elements with depth varies according element and to the different soil profiles due to variations in mobility characteristics, oxidation or intense leaching, effects of organic carbon contents and iron/ manganese co - precipitation under humid climate. The concentration range of these elements is as follows: $\mathrm{Cu}-9-450$ $\mu \mathrm{gg}^{-1}, \mathrm{Zn}-109-327 \mu \mathrm{gg}^{-1}, \mathrm{Mn}-117-1571 \mu \mathrm{gg}^{-1}, \mathrm{Cr}-$ $48-281 \mu \mathrm{gg}^{-1}, \mathrm{Ni}-5-990 \mu \mathrm{gg}^{-1}, \mathrm{Ba}-19.7-94 \mu \mathrm{gg}^{-1}$, $\mathrm{Sr}-11.2-40 \mu \mathrm{gg}^{-1}$, and $\mathrm{Zr}-13-513 \mu \mathrm{gg}^{-1}$. The $\mathrm{Cu}$ content is $304 \mu \mathrm{gg}^{-1}$ in Ap horizon but decreases to 42 to $43{\mu \mathrm{gg}^{-1}}^{-1}$ genetic Bt horizons( $\left.\mathrm{P} 1\right)$ while in Chingavanam series (P2), the $\mathrm{Cu}$ content is $64 \mu \mathrm{gg}^{-1}$ in Ap horizon but reached to $450{\mu g^{-1}}^{-1}$ in 2 layer with its concentrations varying from 55 to $74{\mu g^{-1}}^{-1}$. In Kanjirapalli series (P3), the $\mathrm{Cu}$ content is $17 \mu \mathrm{gg}^{-1}$ in $\mathrm{Ap}$ horizon but varying from 20 to $59{\mu g g^{-1}}^{-1}$ genetic layers with maximum value of $251(\mathrm{Bt} 3)$ to $316 \mu \mathrm{gg}^{-1}$ (Bt5) . The Cu content in Athirampuza (P4) is $15 \mu^{-1}$ in Ap layer, 9 to $18 \mu \mathrm{gg}^{-1}$ in B horizon with $162 \mu \mathrm{gg}^{-1}$ in $\mathrm{Bt} 2$ layer (Table 3). The $\mathrm{Cu}$ anamolies are well expressed due to greater dispersion of $\mathrm{Cu}$ in iron rich lateritic soils. The $\mathrm{Zn}$ contents are more than $200 \mathrm{\mu gg}^{-1}$ in genetic horizons of $\mathrm{P} 1$ and $\mathrm{P} 2$ as compared to $\mathrm{P} 3$ and P4. The mean $\mathrm{Zn}$ concentration is $180 \mu \mathrm{gg}^{-1}$ which is three times more than world average for soils (90 $\mathrm{mg} / \mathrm{kg}$, Bowen, 1979). The surface enrichment of Mn contents (268 to $535{\mu \mathrm{gg}^{-1}}^{-1}$ in A horizons of all soils with decreasing values in $\mathrm{Bt}$ horizons except in P3 where its concentration reached to more than $700 \mu^{-1}$ In $\mathrm{Bt} 1$ and $\mathrm{Bt} 2$ layers. The $\mathrm{Ni}$ contents are less than $100{\mu g^{-1}}^{-1}$ P1 and P2 but reached to a maxima of $990 \mu \mathrm{gg}^{-1}$ in Bt2 horizon of P3 and $415 \mu \mathrm{gg}^{-1}$ in BC horizon of $\mathrm{P} 4$. The mean Ni content is $220 \mu^{-1} g^{-1}$ which is almost four times higher than world average for soils (60 mg/kg, given by Bowen, 1979). Comparing the Ni contents $\left(>200 \mu \mathrm{gg}^{-1}\right)$ with the Great London Council (2001), these soils are registered as contaminated. The strong negative relation of $\mathrm{Ni}$ with $\mathrm{SiO}_{2}\left(\mathrm{r}=-0.51^{* *}\right.$, significant at $1 \%$ level) indicating its decrease with 


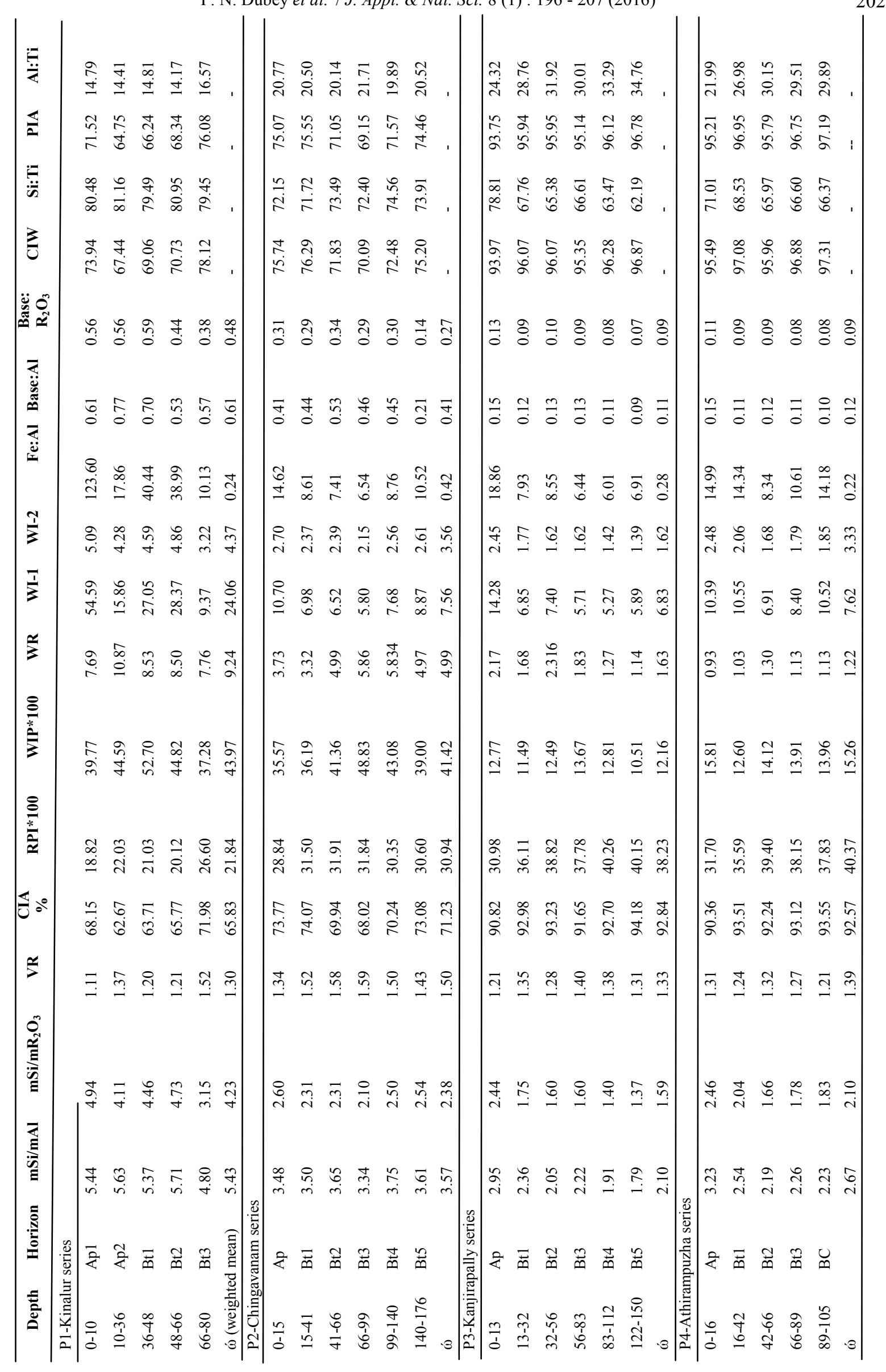


increase of $\mathrm{SiO}_{2}$ but has a strong relation with $\mathrm{Al}_{2} \mathrm{O}_{3}(\mathrm{r}$ $=0.67 * *)$ suggesting the occurrence of $\mathrm{Al}$ rich phases such as clay minerals excert significant control on abundance of Ni (Al Chalabi, 2004). The Cr contents varied from 48 to $167 \mu \mathrm{gg}^{-1}$ with mean of $94.9 \mu \mathrm{gg}^{-1}$

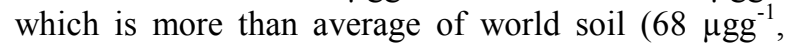
Callender, 2004). The mean strontium content is 23.62 $\mu \mathrm{gg}^{-1}$ with strong positive relation with $\mathrm{SiO}_{2}(\mathrm{r}=$ $\left.0.48^{* *}\right)$ and $\mathrm{MgO}\left(\mathrm{r}=0.78^{* *}\right)$ suggesting its strong association with plagioclase feldspars. The source of $\mathrm{Sr}$ is andesine and presence of $\mathrm{Zr}$ in these soils can be explained by presence of plagioclase feldspars. It was reported by Brantley et al. (1999) that Sr releases from feldspar at $\mathrm{pH} 3.0$ where bytownite releases $\mathrm{Sr}$ by factor of 60 to 400 times than anorthite and microcline respectively. The $\mathrm{Ba}$ content is $47.84 \mu \mathrm{gg}^{-1}$ with strong positive correlation with $\mathrm{CaO}\left(\mathrm{r}=0.67^{* *}\right)$ and $\mathrm{K}_{2} \mathrm{O}(\mathrm{r}$ $=0.77^{* *}$ ). Alkalis and alkaline earth elements, such as $\mathrm{K}, \mathrm{Na}$ and $\mathrm{Sr}$, are the most active elements and easily removed from the profile during chemical weathering (Nesbitt et al., 1980). This can be inferred from the major and trace element records that these soils are intensively weathered under tropical monsoon climate with an annual precipitation more than $2000 \mathrm{~mm}$ and the consecutively trapping Sr by clay minerals.

Soil grouping: The horizon wise major and trace elemental concentrations in these soils are grouped into four clusters (Fig.2) that displayed different patterns of dominance of these elements as shown below.

The major element concentration pattern in Group-1 and 2 is similar with an order of $\mathrm{Si}>\mathrm{Al}>\mathrm{Fe}>\mathrm{Na}>$ $\mathrm{Ti}>\mathrm{Ca}>\mathrm{K}>\mathrm{Mg}$ with $\mathrm{Cr}>\mathrm{Ba}>\mathrm{Cu}$ in Group-1 and $\mathrm{Cu}>\mathrm{Cr}>\mathrm{Ba}$ in Group-2 soils whereas $\mathrm{Si}>\mathrm{Al}>\mathrm{Fe}>$ $\mathrm{Ti}>\mathrm{K}>\mathrm{Ca}>\mathrm{Mg}>\mathrm{Na}$ with $\mathrm{Zr}>\mathrm{Ni}>\mathrm{Mn}$ in Group-3 to $\mathrm{Ni}>\mathrm{Mn}>\mathrm{Zr}$ in Group-4 soils (Table 4). In all soils ferric iron oxide is enriched in the lower and intermediate horizons while enrichment of titanium in Group3 and Group-4 is controlled by the original mafic lithology that bears remarkable high percentages of titaniferous pyroxenes and $\mathrm{Fe}-\mathrm{Ti}$ oxide minerals (Moufti, 2010).

Weathering indices: Chemical weathering indices are commonly used for characterizing weathering intensity of four lateritic profiles of Kerala by incorporating bulk major elemental oxide chemistry in a single metric (Table 5). The indicies are based on the principle that the ratio between concentrations of mobile (such as $\mathrm{SiO}_{2}, \mathrm{CaO}, \mathrm{MgO}$, and $\mathrm{Na}_{2} \mathrm{O}$ ) and immobile elements $\left(\mathrm{Al}_{2} \mathrm{O}_{3}, \mathrm{Fe}_{2} \mathrm{O}_{3}, \mathrm{TiO}_{2}\right)$ should decrease over time as leaching progresses (Souri et al., 2006). The ratio's of more active elements to that of more stable elements, like the molecular ratio of $\mathrm{Si}$ to $\mathrm{Al}$ or $\mathrm{Si}$ to $(\mathrm{Al}+\mathrm{Fe})$, have been used in soil genesis studies for a long time to judge soil weathering degree and as criteria in soil genetic classification systems.

The molar ratio of $\mathrm{Si}$ to $\mathrm{Al}$ (Ruxton, 1968), used to evaluate loss of $\mathrm{SiO}_{2}$ with weathering that shows less than 2 in kandic horizons of Kanjirapalli series (P3) indicating presence of kaolinite and $\mathrm{Al}$ chlorite with more weathering. The wider ratio's $(>3)$ in $\mathrm{P} 1$ is an indication of persistence of primary minerals such as quartz and muscovite and the values in between 2 and 3 in other soils is an indication of moderate weathering. This observation is further confirmed with silica to sesquioxide ratio $\left(\mathrm{SiO}_{2} / \mathrm{R}_{2} \mathrm{O}_{3}\right)$. The classification is possible on the basis of geochemistry of this ratio (Gidigasu, 1976). The ratio is in between 1.33 to 2.0 in kandic horizons of P3 and P4 to define as lateritic (Raychaudhuri, 1980, Burke et al., 2006) whereas in other soils this ratio is above 2 to define as non lateritic tropical soils. The Kanjirapalli (P3) and Athirampuzha (P4) soils are subjected to intensive continuous weathering with hydrolysis of silicates, processes of argillation (mobilization and accumulation of clay particles due to sudden wetting of dry soils under extreme acid condition) and rubification (transformation of ferric oxide to bright red hematite). It was recognized that Fe and $\mathrm{Al}$ are retained preferentially because of the precipitation of poorly crystalline soild phases (e.g, ferrihydrite) from supersaturated solutions (Chadwick et al., 2003). These ferrallitic soils are characterized by low silica to sesiquioxide ratio and base saturation. The other soils are fersiallitic soils with this ratio more than 2. These soils are further divided based on base saturation less than 35 (P3 and P4) and moderate to high (Kalpage, 1974).

Vogt residual index values in these soils vary from 1.21 to 2.07 showing slight variations with depth and are less than 1.4 in majority of kandic horizons. The low vogt ratio corresponds to $\mathrm{pH}$ values between 3.8 to 5.3and found to be less effective in capturing weathering trends in lateritic profiles. The chemical index of alteration (CIA), Harnois chemical weathering index (CIW) and plagioclase index of weathering (PIA) are more than 90 in P3 and P4 indicating high degree of weathering as reported in lateritic profiles of Kerala (Sanjinkumar et al., 2011). The rationale of the CIA is to give a quantitative measure of feldspar weathering by relating $\mathrm{Al}$ to $\mathrm{Na}, \mathrm{Ca}$ and $\mathrm{K}$, which should be removed from a soil profile in the course of plagioclase and K-feldspar weathering (Nesbitt and Young, 1982). The CIA values more than 90 in P3 and P4 indicates intense chemical weathering correspond to $\mathrm{pH}$ values less than 4.5 whereas CIA values less than 75 in P1 and P2 indicates less intensely weathered with a corresponding $\mathrm{pH}$ more than 4.7. The assumption that $\mathrm{Ca}$, $\mathrm{Na}$ and $\mathrm{K}$ decrease as weathering intensity increases and that Al stays mostly immobile (Kirkwood and Nesbitt, 1991) is valid here. These results are in accordance with observations in other weathering studies and theoretical considerations of the element behavior, suggesting that $\mathrm{K}$ release is small compared to the $\mathrm{Na}$ release. This is due to stronger weathering resistance of $\mathrm{K}$ phases such as $\mathrm{K}$-feldspar and due to the fixation of K on clay minerals (Yang et al., 2004 and Reeder et al., 2006 ). Moreover, high CIA values, suggest deri- 
vation from a stable terrain (autochthonous in nature) of SMZ of Kerala (Hossain et al., 2010). The high PIA values (P3 and P4) further indicate that the plagioclases in parent rock displayed increasing chemical weathering with steadily decreasing contents of plagioclases and enriched in secondary aluminous clay minerals (Roy et al., 2008). These indices illustrate the relative loss of $\mathrm{Ca}, \mathrm{K}$ and $\mathrm{Na}$ very rapidly in humid tropical environments and are perhaps more suitable for the study of early stages of rock weathering rather than for well-developed tropical soils. Given the formulations of weathering indices such as molar ratio of $\mathrm{Si}$ to Ti, Parker index and weathering ratio shows decreasing values signifying greater weathering in P3 and $\mathrm{P} 4$ as compared to the other soils under study. The parker index values less than 15 in $\mathrm{P} 3 / \mathrm{P} 4$ and more than 40 in $\mathrm{P} 1 / \mathrm{P} 2$. The kind variations in parker index were reported in highly weathered soils by Eswaran and Raghu Mohan (1973). The similar trends of weathering ratio's are recorded with its values of less than 2 in $\mathrm{P} 3 / \mathrm{P} 4,9.24$ in $\mathrm{P} 3$ and 4.99 in $\mathrm{P} 2$. The indices CIA and CIW are perhaps more suitable for the study of early stages of rock weathering rather than for welldeveloped tropical soils The serious loss of bases in these soils is evident with bases to alumina and sesiquioxide ratios $(<0.5)$. The molar ratio of $\mathrm{Al}$ to $\mathrm{Ti}$ do not show any trends with respect to soils but its values vary from 9.67 to 34.76 . The ratio is more than 20 in P2, P3 and P4. In general, the values of WPI, PI, Si-Al, $\mathrm{Wp}$ and MWPI decrease as the weathering grade or density increases. This is in accordance with findings from Jayawardena and Izawa (1994) and Gupta and Rao (2001). Decreasing values of WPI, MWPI and Wp indicated decreasing mobile cations and increasing hydroxyl water with increasing weathering. Decreasing $\mathrm{PI}, \mathrm{Si}-\mathrm{Al}$ and Si-Ti values are indicative of a decreasing silica content. It can be seen that there was a sharp decrease in these particular weathering indices from the highly weathered granite to granite saprolite state and this confirms the field observations of the abrupt change between the weathered rock and saprolite. Alternatively, CIA, CIW and loss on ignition showed a continuous increase with increasing degree of weathering. This can be attributed to the loss of mobile cations and alteration of the crystal structure, hence the increase in hydroxyl water.

It is interesting to note that high degree of weathering in $\mathrm{P} 3 / \mathrm{P} 4$ profiles is reflected by low $\mathrm{SiO}_{2} / \mathrm{R}_{2} \mathrm{O}_{3}$ ratios and high CIA, PIA and CIW (Ranger, 2002). The triangular plots of $\mathrm{SiO}_{2}-\mathrm{Al}_{2} \mathrm{O}_{3}-\mathrm{Fe}_{2} \mathrm{O}_{3}$ clearly shows that these soils are subjected to weak laterization in $\mathrm{P} 1$, moderate in case of $\mathrm{P} 2$ to strong laterization process in P3/P4 (Schellmann, 1981). The differential rates of weathering in other profiles is due to prevalence of tropical monsoonic climate triggering the mechanism of chemical weathering and also by anthropogenic activities such as improper land use practises on sleep slopes (Topioca and banana cultivation) and deforestation further accelerating chemical weathering in the region (Sanjinkumar et al., 2011). It is further reported that the nature of clay minerals formed due to weather differs with intensity and duration of rainfall. The weathering profiles under high rainfall $(300 \mathrm{~cm})$ have clays, aluminium hydroxides and $\mathrm{Fe}-\mathrm{Al}$ Oxides but in rain shadow zones $(<200 \mathrm{~cm})$ have complex clay mineralogy and absence of or low Fe-Al oxides in the clay fraction (Deepthy and Balakrishnan, 2005).

The applicability of the various weathering indices to different material types and weathering conditions has long been a source of debate. Parker (1970) stated that the Silica-Alumina Ratio was restricted as to its use because the amount of sesquioxides must remain approximately constant during weathering and there must preferably be no formation of smectites or vermiculites as initial weathering products. Harnois (1988) reported that the use of $\mathrm{K}_{2} \mathrm{O}$ as a mobile component in the CIA, WPI and MWPI limits their application to soils in which potassium has been leached, as potassium, through its high exchange capacity can be adsorbed onto other clays in the weathering profile, thus masking its mobility. The Vogt ratio uses $\mathrm{K}_{2} \mathrm{O}$ as an immobile component which contradicts the evidence that potassium is commonly leached. The common point made by all of these authors is that for chemical weathering indices to be effective, an understanding of the geochemical composition and nature of geochemical processes and trends of the particular material of interest is required for the successful application of any weathering index.

\section{Conclusion}

The geochemical properties of four representative ferruginous soils of Kerala showed strong laterization in Kanjirapalli (P3) and Athirampuzha (P4), weak laterization in Kinalur (P1) and moderate laterization in case of Chingavanam series (P2). These soils have Vogt residual index values less than 1.4 in majority of kandic horizons with chemical index of alteration (CIA), chemical weathering index (CIW) and plagioclase index of weathering (PIA) more than 90 in P3 and $\mathrm{P} 4$ indicating high degree of weathering. The enrichment index values more than 1 in majority of soil horizons of Kanjirapalli series (P3) in BC layers of Athirampuzha series (P4) and in Bt5 horizon of Chingavanam series (P2) indicated the high concentration of $\mathrm{Ni}$ and $\mathrm{Sr}$ thatassociation with $\mathrm{SiO}_{2}, \mathrm{Al}_{2} \mathrm{O}_{3}$ and $\mathrm{MgO}$ suggestthe occurrence of $\mathrm{Al}$ rich phases such as clay minerals which exert significant control on abundance of $\mathrm{Ni}$ and strontium content. The kandic horizons with set of properties of ferralic horizon and mollic top soil properties (intensive rubber growing area and frequent additions of leaf) with $\mathrm{pH}<5.0$ must be considered to be placed at subgroup level of Ultisols.

\section{ACKNOWLEDGEMENTS}

This research was carried out under an institutional project at the ICAR-National Bureau of Soil Survey 
and Land Use Planning, Nagpur.

\section{REFERENCES}

Abbaslou, H., Abtahi, A. and Baghernejad, M. (2013). Effect of weathering and mineralogy on the distribution of major and trace elements (Hormozgan province, Southern Iran) Int. J. Forest, Soil and Erosion, 3(1): 15-25.

Al chalabi, S.N.A. (2004). Minerology and origin of chromate in qalander area, Northern Iraq. MSc. Thesis.Salahaddin University-Erbil., Iraq,104pp.

Bhaskar, B.P. and Subbaiah, G.V. (1995). Genesis, characterization and classification of laterites and associated soils along the east coast of Andhra Pradesh. Journal of the Indian Society of Soil Science, 43(1): 107-112.

Bhaskar, B.P., Raja, P. and Srinivas, C.V. (1999). Genetic interpretation of pedological characteristics of laterite associated soils of somasila project, Andhra Pradesh. Gondwana Geological Magazine, 14(2): 39-47.

Bhaskar, B.P., Saxena, R.K., Vadivelu, S., Baruah, U., Butte, P.S. and Dutta, D.P. (2005). Pedogenesis in high altitude soils of Meghalaya plateau. Agropedology, 14(1): 9-23.

Bhaskar, B.P.; Saxena, R.K.; Vadivelu, S.; Baruah, U.; Dipak Sarkar;Raja, P.; Butte, P. S. (2009). Intricacy in classification of pine-growing soils in Shillong Plateu, Meghalaya, India. Soil Survey Horizons. 50 (1): 11-16.

Bhattacharyya, T., Pal, D.K., Lal, S., Chandran, P. and Ray, S. K. (2006). Formation and persistence of Mollisols on Zeolitic Deccan basalt of humid tropical India. Geoderma, 136: 609-620.

Bhattacharyya, T., Sarkar, D., Sehgal, J.L., Velayutham, M., Gajbhiye, K.S., Nagar, A. P., Nimkhedkar, S. S., 2009. Soil Taxonomic Database of India and the States (1:250, 000 scale), NBSSLUP Publ. 143, NBSS\&LUP, Nagpur, India, (266 pp).

Birkeland, P.W. (1999). Soils and Geomorphology. Oxford Univ.Press, New York. 430 pp

Bourgeon, G. (1989). Explanatory booklet on the reconnaissance soil map of forest area Western Karnataka and Goa. Institut Francais de Pondichery, 96 pp. +2 annexes dont 1 carte, 1989, Travauxdela Section Scientique et Technique. Hors Serie N 20, Head of Ecology Department, Institut Francais de Pondichery, e-mail: ifpeco@ifpindia.org. <hal-00504755>

Bowen, H.J.M. (1979). Environmental chemistry of the elements / Academic Press, London, UK, pp.333.

Brantley, S., Cesley, L.J. and Stillings, L.L. (1999). Isotopic Ratios and Release Rates of Strontium Measured from Weathering Feldspars," Geochim. Cosmochim. Acta, 62: 1493-1500.

Burke, C., Benjamin, Heimsath, M. Arjun and White, F. Arthur (2006). Coupling chemical weathering with soil production across soil-mantled landscapes, Earth Surface. Process. Landforms DOI: 10.1002/esp.1443

Callender, E. (2004). Heavy metals in the environment - historical trends. In H.D. Holland, K.K. Turekian (Executive Eds.),Treatise on Geochemistry (pp. 67-105), B.S. Lollar (Volume Ed.). Environmental Geochemistry (Vol. 9). Oxford: ElsevierPergamon.

Chadwick, O.A., Gavenda, R.T., Kelly, E.F., Ziegler, K., Olson, C.G., Elliott, W.C. and Hendricks, D.M. (2003). The impact of climate on the biogeochemical function- ing of volcanic soils. Chemical Geology, 202: 195-223.

Chandran, P., Ray, S., Bhatacharyya, T., Srivastava, P., Krishnan, P. and Pal, D.K. (2005). Lateritic soils (Ultisols) of Kerala, India: their genesis and taxonomy. Australian Journal of Soil Research, 43:839-852.

Chittleborough D.J. (1991). Indices of Weathering for Soils and Paleosols Formed on Silicate Rocks. Austr. J. Earth Sci., 38: 115-120.

Cornu, S., Lucas, Y., Lebon, E., Ambrosid, J.P., Luizãoe, F., Rouillerf, J., Bonnayg, M. and Nealh, C. (1999). Evidence of titanium mobility in soil profiles, Manaus, central Amazonia. Geoderma, 91: 281-295.

Damodaran, A. (1955). Geology of the warkalli formation in parts of Trivandrurn District, Travancore State, Progress report of GSI, (Unpubl.) 1954-1955.

Darmody, R.G., Thorn, C.E. and Allen, C.E. (2005). Chemical weathering and boulder mantles, Kärkevagge, Swedish Lapland. Geomorphology, 67: 159-170.

Deepthy, R. and Balakrishnan, S. (2005). Climatic control on clay mineral formation: Evidence from weathering profiles developed on either side of the Western Ghats. Jour. Earth System Sci., 114: 545-556.

Eswaran, H. and Raghu Mohan, N.G. (1973). The microfabric of petroplinthite. Soil Sci. Soc. Amer. Proc., 37: 7982.

Eswaran, H., De Coninck, F. and Varghese, T. (1990). Role of plinthite and related forms in soil degradation, In Advance in Soil Science, 11: 109-127.

Fedo, C.M., Nesbitt, H.W. and Young, G.M. (1995). Unraveling the effects of potassium metasomatism in sedimentary rocks and paleosols, with implications for paleo weathering conditions and provenance. Geology 23 (10): 921-924.

FAO.(1998). Top soil characterization for sustainable land management. Land and Water Development Division Soil Resources, Management and Conservation Service. Draft. Rome. 1998.51p.

Food and Agriculture Organization of the United Nations. (2006). World reference base for soil resources 2006 A framework for international classification, correlation and communication.World Soil Resource Reports 103. Rome. Italy. $127 \mathrm{p}$.

Gidigasu, M.D. (1976). Laterite soil engineering. Development in geotechnical engineering. Elsevier Scientific Publishing Company.

Gupta, A.S. and Seshagiri Rao, K. (2001). Weathering indices and their applicability for crystalline rocks. Bull. Eng. Geol. Env., 60: 201-221.

Harindranath, C.S., Venugopal, K.R.,. Raghu Mohan, N.G., Sehgal, J.L. and Velayuthm, M. (1999). Soils of Goa for optimising land use. NBSSPubl.74. NBSS \& LUP, Nagpur. P131.

Harnois, L (1988). The CIW index: A new chemical index of weathering. Sedimentary Geology, 55(3-4): 319-322

Hossain, H.M.Z., Roser, B.P. and Kimura, J.I. (2010). Petrography and whole-rock geochemistry of the Tertiary Sylhet succession, northeastern Bengal Basin, Bangladesh: Provenance and source area weathering. Sediment. Geol., 228: 171-183.

Jayawardena, U.deS. and Izawa, E. (1994). A new chemical index of weathering for metamorphic silicate rocks in tropical regions: A study from Sri Lanka. Engineering Geology. 36(3-4): 303-310.

Kalpage, F.S.C.P. (1974). Tropical soils, classification, fertility and management.University of Malya, Kaula Lum- 
pur, pp294.

Kamath, S.U. (1985). Karnataka State Gazetteer: Uttara Kannada District, Gazetteer of India, Government of Karnataka, Bangalore.

Kirkwood, K.A. and Nesbitt, H. W. (1991). Formation and Diagenesis of Weathering Profiles. The Journal of Geol. 97: 129-147.

Krishnan, P., Venugopal, K.R. and Sehgal, J.L (1996). Soils of Kerala for optimising land use. NBSSPubl. 48b . NBSS\& LUP, Nagpur.P 54, Soil Series of India.10.

Little, M.G. and. Aeolus Lee, C.T. (2006). On the formation of an inverted weathering profile on Mount Kilimanjaro, Tanzania: buried paleosol or groundwater weathering. Chemical Geology, 235: 205-221.

Jackson, M.L. (1975). Soil chemical analysis-advanced course. Univ. of Wisconsin, College of Agric., Dept. of Soil Sci., Madison, WI Prentice-Hall, Inc., Englewood Cliffs, NJ.

Moufti, A.M.B. (2010). Field, Mineralogical and Geochemical Characteristics of As-Sarat Laterite Profiles, SW Saudi Arabia. JAKU: Earth Sci., 21, (2): 47-75.

Nahon, D. (2003). Weathering in tropical zone. Significance through ancient and still active mechanisms. Comptes Rendus Geoscience, 335: 1109-1119.

Narayana Swamy (1992). Geochemistry and Genesis of Laterite in parts of Cannore District, North Kerala. Ph.D thesis. The Cochin University of Science and Technology. pp.1-111

Nesbitt H.W., Markovics, G., and Price R.C. (1980). Chemical processes affecting alkalis and alkaline earths during continental weathering . Geochimica et Cosmochimica Acta. 44: 1659-1666.

Nesbitt, H.W. and Young, G.M. (1982). Early Proterozoic climates and plate motion inferred from major element chemistry of lutites. Nature, 299: 715-717.

Nesbitt, H.W. and Markovics, G. (1997). Weathering of granodioritic crust, long-term storage of elements in weathering profiles, and petrogenesis of siliciclastic sediments. Geochimica et Cosmochimica Acta, 61: 1653 -1670 .

Nesbitt, H.W., Young, G.M., McLennan, S.M. and Keays, R.R. (1996). Effects of chemical weathering and sorting on the petrogenesis of siliciclastic sediments, with implications for provenance studies. The Journal of Geology. 104: 525-542.

Page, A.L., Miller, R.H. and Keeney, D.R. (2002). Methods of Soil Analysis, Prt-2: Chemical and microbiological properties. American Society of Agronomy and Soil Science Society of America, Madison, Wisconsin, pp.159-164.

Pal, D.K., Wani, S.P., Sharawat, K.L. and Srivastava, P. (2014). Red ferruginous soils of tropical Indian environments: A reviewof the pedogenic processes and its implications for edaphology.Catena. 121:260-278.

Parker, A. (1970). An Index of Weathering for Silicate Rocks, Geol. Mag., 107: 501-504.

Price, J.R. and Velbel, M.A. (2003). Chemical weathering indices applied to weathering profiles developed on heterogeneous felsic metamorphic parent rocks. Chemical Geology, 202: 397-416.

Price, R.C., Gray, C.M., Wilson, R.E., Frey, F.A. and Taylor, S.R. (1991). The effects of weathering on rare-earth element, $\mathrm{Y}$ and $\mathrm{Ba}$ abundances in tertiary basalts from southeastern Australia. Journal of Chemical Geology, 93: $245-265$.
Ramahashay, B.C., Rao, K.S., Mehta, V.K. and Bhavana, P.R. (1987). Minerology and Geochemistry of lateritic soil profiles in Kerala, India. Chemical Geology. 6091 4):327-330.

Ranger, J., Allie, S., Gelhaye, D., Pollier, B., Turpault, M.P. and Granier, A. (2002). Nutrient budgets for a rotation of a Douglas-fir plantation in the Beaujolais (France) based on a chronosequence study. Forest Ecol Manag., 171: 3-16.

Raychaudhuri, S.P. (1980). The occurrence, distribution, classification and management of laterite and lateritic soils. O.R.S.T.O.M., sér. Pédol., uol., XVIII, noa 3-4: 249-252.

Reiche, P. (1943). Graphic representation of chemical weathering. Journal of Sedimentary Petrology, 13: 53-68.

Reeder, S., Taylor, H., Shaw, R.A. and Demetriades, A. (2006). Introduction to the chem-istry and geochemistry of the elements. In: Tarvainen, T., de Vos, M. (Eds.), Geochemical Atlas of Europe. Part 2. Interpretation of Geochemical Maps, Additional Tables, Figures, Maps, and Related Publications. Geological Survey of Finland, Espoo, pp. 48-429.

Rollinson, H.R. (1993). Using Geochemical data: evaluation, presentation, interpretation.Pearson Education Limited, NY, USA, pp.352.

Roy, P.D., M. Caballeroa, R. Lozanoc and W. SmykatzKlossd, 2008. Geochemistry of late quaternary sediments from Tecocomulco lake, central Mexico: Implication to chemical weathering and provenance. Chemie der Erde, 68: 383-393.

Ruxton, B.P. (1968). Measure of the degree of chemical weathering of rocks, J. Geol., 76: 518-527.

Sajinkumar, K.S., Anbazhagan, S., Pradeep kumar, A.P. and Rani, V.R. (2011). Weathering and Landslide Occurrences in Partsof Western Ghats, Kerala. Journal of Geological Society of India, .78: 249-257.

Sarma, V.A.K., Krishnan, P. and Budhihal, S.L. (1987). Laboratory methods -Soil resource mapping of different states in India. NBSS Publ. Technical Bulletin 14. NBSS\&LUP. Nagpur.49p.

Satyanarayana, K.V.S. and Thomas, P.K (1962). Studies on laterite associated soils. II. chemical composition of lateritic profiles. Journal of the Indian Society of Soil Science, 10: 213-222.

Sawarkar, A.R. (1980). Geological and Geomorphological features in part of Nilambur valley, Kozhikkode district, Kerala State with special reference to the Alluvial Gold deposits in the area G .S . I . special publication, $.5: 29$ 37.

Schellmann, W. (1981). Consideration on the definition and classification of laterites. In Leterization process. Proceedings of International Seminar on Laterization process. Trivandrum, India. pp1-10. Geological Society of India, Kolkata.

Sehgal, J., Mandal, D.K., Mandal, C. and Vadivelu, S. (1992). Agroecological regions of India. Second edition. Technical bulletin. NBSS\&LUP, Publ.24. P.130. NBSS\&LUP, Nagpur.

Sehgal, J. (1998). Red and lateritic soils: an overview.in: J. Sehgal, W.E. Blum, K.S. Gajbhiye (Eds.), Red and Lateritic Soils, Managing Red and Lateritic Soils for Sustainable Agriculture, 1, Oxford and IBH Publishing Co. Pvt. Ltd., New Delhi (1998), pp. 3-10

Souri, B., Watanabe, M. and Sakagami, K. (2006). Contribution of Parker and Product indexes to evaluate weather- 
ing condition of yellow brown forest soils in Japan. Geoderma, 130: 346-355.

USDA, NRCS. (2008). Official Soil Series Descriptions. Available online at (verified 7 May 2008). a.Official Soil Series Descriptions. Available online at http: // soils. usda. Gov / technical / classification / osd / index. html (verified 7 May 2008). 2008.

Vogt, T. (1927). Sulitjelmefeltets geologiog petrografi. Norsk Geologisk Tidsskrift, 121: 1-560.

Wei G., Ying, L., Xianhua, L., Lei, S. and Dianyong, F. (2004). Major and trace element variations of the sediments at ODP Site 1144, South China Sea, during the last $230 \mathrm{ka}$ and their paleoclimate implications. Palaeogeogr. Palaeocl. 212: 331-342.
Yang, S.Y., Li, C.X., Yang, D.Y. and Li, X.S. (2004). Chemical weathering of the loess deposits in the lower Changjiang Valley, China, and paleoclimatic implications. Quaternary International, 117, 27-34

Yousefifard, M., Youbi, S.A., Jalallian, A., Khadun, H. and Makkizaddi, M.A. (2014). Mass balance of major elements in relation to weathering in soils developed on Igneous rocks in semi arid region, North Western Iran. J. Mt. Sci., 9: 41-58.

Zabel, M., Schneider, R.R., Wagner, T., Adegbie, A.T.,.Vries, U.D and Kolonic, S. (2001). Late Quaternary climate changes in central Africa as inferred from terrigenous input to the Niger fan . Quaternary Research, 56: 207-217. 